\title{
Academicians Satisfy of The Faculty of Economics, in Universitas Negeri Surabaya Throught on Total Quality Management
}

\author{
Susi Handayani ${ }^{{ }^{*}}$ and Pujiono ${ }^{2}$ \\ Surabaya State University, Surabaya, Indonesia
}

\begin{abstract}
The Faculty of Economics in Universitas Negeri Surabaya had certified of International standard operating (ISO) for quality management since 2015. This certification prosecutes management of faculty of economics to increase service quality to academicians. The important aspects of ISO have to determine TQM implemented. Therefore, it had created quality assurance team that exist gradually at university to study program. A service quality must be guarantied by internal and external audit. However, it improves continuous improvement that based on audit results, especially low students satisfaction, officer alacrity to give a service, ability to explanation, handling of complaints, courtesy and friendliness, and support infrastructures for learning process. All cost of quality assurance conduct to prepare an audit internal implementation, to up-date accreditation forms and performance of study program, and monitoring and evaluation for learning and curriculum, improve a quality procedure, prepare and evaluation a quality target, and follow up on audit finding.
\end{abstract}

Keywords: ISO, service quality, student satisfaction, total quality management

\section{INTRODUCTION}

The existence of ASEAN economics community have impacted to all organization that shoud to do quality increasing so that ability high competitive advantage. In hence, this is free stream human resources among ASEAN countries so human resources have a certainly qualified. Quality human resources can be generated by educational institutions that are also qualified through a higher education. According Widarto (2012), higher education is one institutions that have a very large role and effective way to prepare qualified human resources. It motivates all higher education that improves with the goal of increasing the quality of human resources generated. Higher education institutions have the responsibility to generete the quality graduates. Furthermore, they can not just rely on an input quality because student's ability is various. Therefore, they revamp all sector as follows: higher education management, activity process to obtain graduation, academic staff, and infrastucture. Development meant that is occured a quality enhancement of graduates. One of stragtegies conducts to result that through out total quality management implemented.

Total quality management based on the bible (in Sudarsono, 2014) consitutes concept of quality management that is comprehenship to modern orientation that base on combination of management tool, effort, inovation, and special skilll to

* Corresponding author. Email address: susihandayani_76@yahoo.com 
increase perfoemance and contionous improvement. Organization that implemented total quality management always do effort to contionous improvement (Tanner and Detoro in Supriyono, 2011) as follows: customer focus, improvement process, and total involvement. Mean while, Sallis (1993) explained that education quality was focused on to internal and external academicians at faculty of ecoomics. Associated with total quality management, faculty of economics in Universitas Negeri Surabaya have owned certified of International Standard Operation for quality management since 2015. This cerificate sue to enhence quality so academicians can be satified. Academicians that means is faculty of economics' student. For institutions that was certified by ISO, it should be consider a important aspect in total quality managment. A important aspect that means is customer satisfaction level, in this case the student of the faculty of economics. According with student satisfaction level of the faculty of economics in 2015, team quality assurance had measured. The result is good enough and do not meet a minimum value that was expected namely number 70 . Therefore, further research is actually how the level of student satisfaction in the faculty of economics in Universitas Negeri Surabaya after ISO certified which means that FE has implemented TQM system. In this study will attempt to describe how the level of student satisfaction on aspects of quality of services and how committed management after the adoption of the ISO. It is very necessary especially the faculty of economics in Universitas Negeri Surabaya management commitment, considering the whole management environment the faculty of economics in Universitas Negeri Surabaya is new, so that they understood and implemented the purpose certified ISO.

In addition, the things mentioned earlier with regard to human resources, there are other things that also need to be identified with regard to costs. Cost is incurred denote Faculty of Economics in Universitas Negeri Surabaya relating to quality assurance activities. It is often referred to as quality cost as it aims to improve quality. Based on the above exposure, it needed the research that is to analyze the level of satisfaction of the academic community at the Faculty of Economics in Universitas Negeri Surabaya. It also analyzes the amount of quality costs already incurred Faculty of Economics in Universitas Negeri Surabaya. This relates to the faculty of economics in Universitas Negeri Surabaya that has been certified ISO quality management as a form of implementation of total quality management.

\section{LITERATURE REVIEW Preliminary Study}

Study on total quality management (TQM) have been carried out by prior reseacher. Sudarsono (2014 conducted research on measuring the Total Quality Management at the University that TQM is a philosophy of quality improvement continuous and practical tools that can be used educational institutions to meet the needs, desires and expectations of today's customers and future field of education. Important tool is the self measurement, benchmarking, and ISO. TQM in higher education, there are several things including: the students, the number of faculty, curriculum, administration, leadership, physical potential, public relations around the university, etc.

Supriyanto (2011) studied on the implementation of TQM in quality management system of learning in the Faculty of Education, University Negeri 
Malang, showed that the successful implementation of TQM review of aspects of the formulation of objectives to improve the quality, the application of TQM principles in the quality management system (QMS) as well as a supporting component implementation TQM in QMS. In addition, management commitment and quality assurance team is very positive for the sustainability of the QMS learning support overall performance. The other study was conducted Widarto (2012) on the implementation of TQM in the Faculty of Engineering in University Negeri Yogyakarta. The results showed that the major requirement in implementing a quality management system is the commitment of the top management (Dean) which can be shown by appointing First Vice Dean as the head of the team of quality management system. Besides that, Dean also must ensure that TQM is applied on the faculty as appropriate. Furthermore Dean formed a design team of quality management system.

This research is done to continue the previous research results, but on the object with characteristics somewhat different. This is done because the object of this study is the Faculty of Economics in Universitas Negeri Surabaya that has been certified ISO quality management. Further in this study will be discussed more widely than previous studies because it also exIQAnes how the satisfaction of the academic community of the Faculty of Economics after the ISO certification as well as the cost of quality has been issued it with the aim of quality improving. The results of this study are expected to provide input for the Faculty about any matters that still need to be improved and upgraded. The next input is as a basis for generating faculty policy.

\section{Theories about Quality}

Total Quality Management (TQM) is a philosophy of continuous improvement, which can provide a set of practical tools to every educational institution to meet the needs, desires, expectations of its customers, now and for the foreseeable future. Implementation of TQM in education can be realized with the following principles: (1) Focus on the customer (customer focus). Key to the success of integrated quality culture namely the existence of an effective relationship, both internally and externally, between the customer and supplier. (2) process improvement. Improving the quality of the process refers to the continuous improvement (continuous) built on the work that will produce a series of stages interrelation and activities that will ultimately result in output (output). (3) total involvement all components of education starting from the leadership to the teachers and education personnel. In connection with the higher education environment, quality improvement can be achieved by: (1) Improving the quality of teachers and staff. The creation of a conducive working environment as a result of cultural change, all members of the organization, including the leaders, must be prepared to follow the program of education and training in total quality. (2) The professionalism and focus on academics. There is another dimension of professional workers in education who have traditionally viewed themselves as protectors of the quality and standards of the institution. The combination of the best aspects of professionalism with integrated quality is essential to achieve success, such as: management of the curriculum in an effort to improve and develop the quality of education, towards the creation of intelligent life, peaceful, open, democratic, and able to compete, both nationally and internationally; maintaining relationships with the academic community. Leaders of educational institutions 
need to develop a paradigm that must prioritize and satisfy the academic community. To support the improvement of the quality of all educational institutions associated with the institution (faculty leaders, faculty, staff, students, and community) must work together and really strive to make improvements the education quality.

Embodiments of TQM applications, among others through the implementation of quality management system (ISO 9001: 2008). It is a management system to direct and control an organization with regard to quality. Implementation systems can assist organizations in improving confidence and satisfaction through the provision of better quality assurance. Satisfaction is a feeling or attitude towards products/services after the use of a particular product or service. Satisfaction can be demonstrated by spreading positive messages related products/services. If not satisfied, it is likely to switch to the service/product to another of the same. Not only that, dissatisfaction will be reflected in the negative words that will impact on the company's ugly. Tjiptono (2006) explained several methods for measuring satisfaction, among others: (1) The system of complaints and suggestions, every company needs to provide an opportunity for customers to submit suggestions, opinions and complaints; (2) Survey of satisfaction, satisfaction measurement can be done by asking directly, the question could be related to two things, such as certain attributes and expectations on the magnitude of the performance they feel (Indrawati, 2011).

In this study as a customer Faculty of Economics, University of Surabaya is the academicians. Setyaningsih (2008) argued that in the context of the education agency that referred customers were students, educators, and staff, as well as other parties involved in creating high-quality graduates.

The benefits of implementing a Quality Management System (ISO 9001: 2008), among others:

1. The competition and increasing company image with ISO 9001: 2008.

2. Implementation of ISO 9001: 2008 will increase productivity, efficiency, operational effectiveness and reduce the costs incurred defective items (reject) or low-quality goods and waste.

3. Creating a working system within a company is a documented standard work and has a good working rule making it easier to control.

4. Could functionate as a standard work to train a new employee.

5. Ensure that the process is carried out in accordance with established quality management system.

6. It would be easier for top management in achieving the target because it prepares measurable goals and an achievement.

7. Improve the spirit and morale of employees because of their lack of clarity in the duties and authority (Job Description) and the relationship of the parts associated so that employees can work efficiently and effectively.

8. Could direct to employees to insightful a quality to meet customer demand, both internal and external.

Eight quality management principles that are the basic rules for leading and implementing an organization, include: customer focus, leadership, involvement of people, process approach, system approach to management, continual improvement, factual approach to decision making, and mutually beneficial supplier relationships. In its application the company will follow the requirements 
set out in the International Standard ISO 9001: 2008 consists of five major elements, namely:

1. Quality Management Systems: requirements and documentation Requirements.

2. Management Responsibility: management commitment, focus on academic civitas school of economics, quality policy, planning, responsibility, authority and communication, management review.

3. Resource Management: provision of resources, human resources, infrastructure, work environment.

4. Product Realization: planning product realization, process relating to academicians of the faculty of economics, design and development, purchasing, production supply and services, control of monitoring and measuring equipment.

5. Measurement, Analysis and Improvement: monitoring and measurement, control products not available, data analysis, improvement.

In the discussion about the quality can not be separated with the quality costs. To support the results quality is expected to have relevance within the analytical framework proposed by Juran, R. (1985). The analytical framework is often called Juran's Perspective that is used to measure and monitor the quality cost. In general, quality costs consist of the cost of prevention appraisal, internal failures, and external failure. First, the cost of prevention is a cost to be borne when the products (goods or services) generated apparently not / does not meet quality standards. Second, the cost of Appraisal (appraisal cost) are costs that are used to monitor all activities in delivering products (goods or services) in order to comply with quality standards. Furthermore, the internal failure costs are the cost that is used to improve the quality found by internally before such products exit from the institution. These costs can include the cost of rework. Lastly, the external failure costs are costs incurred to repair the product when the product is to welcome customers. An example is the cost of a warranty claim.

\section{RESEARCH METHODS}

This study used a qualitative approach. This research was conducted to gain a better understanding of the complexities related to the quality that is in the economic faculty of the State University of Surabaya. It generates descriptions of activities conducted in the Faculty of Economic in Universitas Negeri Surabaya in efforts to improve quality. This study will be explained based on existing data so it does not do any treatment.

The data used in this research is quantitative and qualitative data. The quantitative data in the form of a figure showing score of the level of satisfaction of the academic community at the Faculty of Economic in Universitas Negeri Surabaya. In addition there are qualitative data on activities quality assurance team of the Faculty of Economics, and management in the environment of Faculty in an effort to improve the quality. Activity is associated with the process of implementing quality assurance (TQM and ISO) include: vision and mission, quality, quality objectives, procedures quality, management commitment, as well as the commitment of a team of quality assurance.

Source in this study is consist of primary and secondary data. Primary data was collected by questionnaire that be distributed to the respondents. Mean while, 
the secondary source in the form of documents that support the fulfillment of the quality-related data including ISO quality management. Respondents in this study consisted of all parties involved in efforts to improve the quality of Faculty of Economics in Universitas Negeri Surabaya, among others: team group quality assurance, a team of quality assurance unit (UPM), Dean, Chairman/Head of Department, and Head of laboratorium as well as samples of students, educators and education personnel.

Data collection techniques used, in this study, includes interviews and obsevations which were used to record opinions or information related to quality assurance activities. In addition, technical documentation of archives and records is a testament to a unique organization that is not encountered in interviews and observations. This source is a source of data that can be used to support data from observations and interviews.

To maintain netrality researchers, it is necessary to increase credibility. In this study, the process include: triangulation, researchers to approach the maximum to obtain the data through three processes above the maximum depth. This step was aimed at obtaining the same interpretation of the various parties. It was form with the organization undertakes a review of records that were supported by interviews on related targets; Collaboration, researchers in collaboration with the participant who had the same potential and knowledge and had accessed to the data source. Participant worked to find the data and interpret findings. From this step produced the same description of the outcomes of research.

Data analysis technique was done by recording, interpreting and presenting information. The analysis steps can be done such as: data reduction and literature review. Data reduction is done to reduce data that can be processed to the next step. Further more, this understanding includes therein was the synchronization test findings and literature review. Nextly, understanding of the finding results was finish, the next step was to interpret the data associated with the theory. Each of the findings should be explained and be based on theories related.

\section{RESULT}

\section{Quality Management Systems in the Faculty of Economics}

The TQM in the Faculty of Economics was showed by quality management system implementation after received certification ISO 9001:2008. When it was certified of ISO for quality management since 2015 so entire document at studies program in the faculty of economics has organized with good and easily accessible. It is occured because environmental of the faculty of economics has had a quality policy, quality goals, as well as procedures for the review ensures management quality. The quality procedures at the faculty of economic was showen by Table 1 . The formation process of the quality policy, quality goals, and procedure quality innitiately was contructed by the little team formed by the Dean of the faculty of economics. This three things draft, furthermore, were discussed big group, included board of management, to start from program study level to faculty. In the discussion was accompanied by a consultant. It assisted a small team arranged three things draft. After they was approved in discussion forum consist of draft quality policy, quality objectives and quality procedures then the next three drafts will be ratified by the Dean of the faculty of economics. 
The next stage is formed management representative (MR) by the Dean to coordinate the implementation of quality assurance and it is including to assurance of implementation of quality management 9001: 2008 at the Faculty of Economics environment. The management representative is assisted by a team of faculty quality assurance, which in 2015 serves as the secretariat of the ISO team.

Tabel 1 Quality Prosedure at the Faculty of Economics

\begin{tabular}{ll}
\hline Document controlling & Retirement Employee \\
\hline Record controlling & Periodic Incremental Salary \\
\hline Internal Audit & Demand Petty Cash \\
\hline Customer Satisfaction Measurement & Scholarship management \\
\hline Management review & Management of Student Activities \\
\hline Inprovement and prevention action & Device Development Curriculum \\
\hline Handling Products Not Appropriate & Determination Academic Supervisor \\
\hline Learning Monitoring & Course Scheduling \\
\hline Yudisium and Graduation & Evaluation at Second Semester \\
\hline Letter Administration & Study mutation \\
\hline Procurement of goods / services & Leave study \\
\hline State Property Management & Activity Program for New Student \\
\hline Selection and Evaluation Partner & External relationship \\
\hline Public officer grade & Archieve controlling \\
\hline $\begin{array}{l}\text { Performance measurement of public } \\
\text { officer }\end{array}$ & Measurement of target quality \\
\hline Infrastucture and environment maintenance \\
\hline \multicolumn{2}{c}{ Source: ISO Document at Faculty of Economics }
\end{tabular}

For the technicals was assisted also by a team of quality assurance unit. The role of MR and quality assurance team ensure that the quality management system in Faculty of Economics goes well. Thus, in the early implementation of the quality management system is often conducted meetings for coordination and quality assurance in environmental progress. The next, it is to ensure quality management, and then the economic faculty held internal quality audits (IQA). Every year at the faculty of economics carried out internal quality audits (IQA) at least twice. Surely this is the appropriate quality procedures that have been collated previously. First implementation of IQA held at the end semester, and second it held at the end of odd semester. However, in 2015 turned out to only be implemented once AQI, so that before the implementation of surveillance audits performed one more IQA to meet the minimum execution twice in one year. Surveillance audit is an audit by an external party (the party that has the authority to issue the certificate of ISO 9001: 2008) that were performed to ensure that the quality of environmental management at Faculty of Economics well implemented and sustained. This audit was carried out after the implementation of internal quality audits (IQA).

Internal Quality Audit undertaken to ensure among other things that all quality procedures have been implemented in the faculty of economics. It is also to discuss the level of achievement of quality targets that have been developed previously. The implementation of the IQA in addition carried out by a team of quality assurance unit and the team of quality assurance group, also it was assisted by a lecturer who has been certified internal quality auditors. IQA was done by 
means of cross mechanism auditor team a program of study or area certainly does not come from a program of study or areas to be audited. Lead auditor who coordinated the implementation of the IQA. Lead auditor was a lecturer of the quality assurance team that is selected by the management representative (MR) and approved by the Dean. Each completed implementation of IQA will do a management review meeting to discuss the results and follow-up of the findings that have done all auditee. When the meeting review of quality can be seen management commitment to the quality management.

Implementing of the quality assurance is not only in form the quality audit, however it conducted as monitoring and evaluation the curriculum and learning process. These activities were coordinated by a center quality assurance, which it is a university-level of the quality assurance team. Monitoring and evaluation activities carried out after the exam in the end semester. Monitoring and evaluation of activities coordinated by the center quality assurance but in practice it carried out by a team of quality assurance group and unit. The mechanism of the monitoring and evaluation activities carried out by small teams formed by a team of quality assurance group. This small team tasked to monitor and evaluate a study program curriculum as well as monitoring and evaluation of learning from the planning to evaluation. Monitoring and evaluation learning is done well by following the learning process in the classroom to ensure indicators that file has been performing well. The results reported by the monitoring and evaluation activities at quality assurance group and unit through the Dean.

\section{Management Commitment the Faculty of Economics on Quality Assurance}

Based on, the questionnaires results that were distributed to respondents by the quality assurance team, and then the overall of the top management was committed to improving the quality in the faculty of economics. This is shown by the table 2., it is more than $80 \%$ of respondents think that top management had a high commitment to improving the quality in the faculty of economics.

Tabel 2 Recapitulation of the Management Commitment at Faculty of Economics

\begin{tabular}{lc}
\hline \multicolumn{1}{c}{ Management } & Score \\
\hline Dekan & $92 \%$ \\
\hline Vice Dean 1 $^{\text {st }}$ & $98 \%$ \\
\hline Vice Dean 2 $^{\text {nd }}$ & $83 \%$ \\
\hline Vice Dean 3 $^{\text {rd }}$ & $95 \%$ \\
\hline
\end{tabular}

Source: questionnaires results

Management commitment was also explored to information through questionnaires by the quality assurance team of faculty and department. The results indicated the level of department level management commitment to improving the quality was very varied. As presented in Table 3 showed that the commitment of all good department head. This is shown by more than $80 \%$ of respondents found the head of departments in the faculty of economics is strongly committed to improving the quality of the faculty of economics.

In contrast, the results indicated the level of the department management was various commitment to improving the quality. As presented in Table 3. showed that the enroll commitment was good at the department head. This is shown by 
more than $80 \%$ of respondents found the head of departments in the faculty of economics is strongly committed to improving the quality. However, commitment of the department secretary was shown in Table 3 that the accounting and economics department is good in which more than $80 \%$ if it is compared to commitment of the secretary of the economic education and management department. Nextly, heads of laboratories in accounting department have higher commitment than economics education. Finally, the commitment level management of studi program showed that enroll were more than $80 \%$ of respondents believe that the management's commitment to improving the quality of courses were very good.

Table 3 Recapitulation of the Management Commitment at the Department level

\begin{tabular}{lc}
\hline \multicolumn{1}{c}{ Management } & Score \\
\hline Head of Economics Education Department & $82 \%$ \\
\hline Head of Management Department & $91 \%$ \\
\hline Head of Accounting Department & $93 \%$ \\
\hline Head of Economics Department & $96 \%$ \\
\hline Department Secretary of Economics Education & $71 \%$ \\
\hline Department Secretary of Management & $68 \%$ \\
\hline Department Secretary of Accounting & $82 \%$ \\
\hline Department Secretary of Economics & $96 \%$ \\
\hline Head Laboratory of Economics Education & $71 \%$ \\
\hline Head Laboratory of Accounting & $95 \%$ \\
\hline
\end{tabular}

Source: questionnaires results

Table 4 Recapitulation of the Management Commitment at the Study Program

\begin{tabular}{lc}
\hline \multicolumn{1}{c}{ Management } & Score \\
\hline Head of study Program of economics Eduation & $82 \%$ \\
\hline Head of study Program of the Accounting Education & $82 \%$ \\
\hline Head of study Program of the Office Administration Education & $82 \%$ \\
\hline Head of study Program of the Business Administraion Education & $82 \%$ \\
\hline Head of study Program of Accounting (S1) & $96 \%$ \\
\hline Head of study Program of Accounting (D3) & $89 \%$ \\
\hline
\end{tabular}

Source: questionnaires results

\section{Satisfaction Student of Economic Faculty}

Faculty economy has had a system of e-monitoring and survey which contains a questionnaire to obtain information about the lecture as well as the service during the lecturing progresses. This system was conducted to determine 
the level of student satisfaction as customer economics faculty. Questionnaires in e-monitoring and survey system is filled by all parties as follows: students, lecturer, and staff officer.

To obtain more information, the researchers also conducted to spread questionnaires about the quality of services in the Faculty of Economics. More ever, the service questionnaire were distinguished among each educational department, faculty, and librarians. Results showed that the best administrative services performed by the management department. While the results of the lowest value of the services of the accounting department. Recapitulation results presented in Table 5.

Tabel 5 Recapitulation of the Student Satisfaction for Services of Officer Staff

\begin{tabular}{lc}
\hline \multicolumn{1}{c}{ Department } & Score \\
\hline Faculty & $79 \%$ \\
\hline Library & $80 \%$ \\
\hline $\begin{array}{l}\text { Department of Economics } \\
\text { Education }\end{array}$ & $84 \%$ \\
\hline Department of Management & $85 \%$ \\
\hline Department of Acounting & $77 \%$ \\
\hline
\end{tabular}

Source: questionnaires results

Based on the above presentation, the Faculty of Economics has been certified ISO for quality management since 2015 . It showed that the management system was running well. However, the target value of the level of student satisfaction at the Faculty of Economics still below the targeted value of less than 70. It needs to be investigated related matters what causes the level of student satisfaction was not significantly increased. The results showed that the administration functions of quality assurance in the environment of Faculty of Economics had to function properly. Based on the results of interviews with faculty quality assurance team, the quality assurance process has run well. Besides that, the follow-up of audit findings has also been followed up by the related management. This is evidenced by the results of a questionnaire distributed assessment showed values above 70 . This means that the entire environmental management in faculty of Economics in Universitas Negeri Surabayahave a good commitment to implementing quality assurance.

In addition, the faculty of Economics environment for online monitoring results showed a number less than 70 . So that, it encourages researchers followed up with additional questionnaires used to further explore respondents' opinions relating to the service quality that is still low in value. In contrast, results also show that the level of student satisfaction is still good enough and it was showed with score 77 . This means that the students assess at the actual a service quality in prior survey but in this research that occured increasingly. However, the service still needs to be improved, especially services in accounting department and library that still show its quality services under 80 than other.

\section{The Cost of Quality Assurance Activities at The Faculty Of Economics}

As in the description about the activities of the quality assurance at the faculty of economics have had teams the quality assurance program to assure quality routinely. In the implementation of quality assurance activities needs funding. In 
the faculty of economics expenses to these activities that was started on level study programs, departments, and faculties, even up to university level. The funding for several activities including the following:

1. The preparation of the implementation of internal quality audits,

2. Up-date performance to study program and faculty about accreditation forms,

3. The monitoring and evaluation of learning and curriculum,

4. Adjustment of the quality procedure,

5. The preparation and evaluation to achievement of quality target,

6. Follow up on audit findings both IQA and surveillance audits.

\section{CONCLUSION}

The Faculty of Economic in Universitas Negeri Surabaya has implemented a total quality management (TQM) in the pattern of quality management system. It has been supported by the establishment of quality assurance team hierarchy that was started by university, faculty, and departments level. Implementation of internal and external quality audit is an effort to ensure the quality in Faculty of Economics. However, there are something that need to be followed up immediately to improve the quality, particularly the service quality that include: low levels of customer satisfaction due to the alertness of the officer in providing services; the ability to give an explanation; the ability of education personnel in the handling of complaints; courtesy and hospitality education personnel; and infrastructure supporting the lecture.

Costs associated with quality assurance in Faculty of Economics that was done to fund the preparation of the implementation of internal quality audits, update to many study program performance and faculty about accreditation forms, learning monitoring and evaluation and the curriculum, adjustment of the quality procedure, preparation and evaluation of performance quality targets, as well as follow-up on the implementation of internal quality audits.

\section{SUGGESTION}

For the Faculty of Economics should be train officer staffs to be more polite and friendly in service so that they has an ability to provide an explanation as well as handling the complaint.

\section{References}

Badan Penjaminan Mutu Internal .(2014). Angket Kepuasan Mahasiswa Terhadap Pelayanan Akademik, diakses dari alamat website bpmi.Unp.Ac.Id/.../ Angket\%20kepuasan \%20mhs\%20-\%20\%20akademik.

Bagian Penjaminan Mutu STMIK Atma Luhur. (2014). Laporan Hasil Kuesioner Kepuasan Mahasiswa Terhadap Pelayanan Biro/Bagian Di STMIK Atma Luhur Tahun Akademik 2013/2014 diakses dari alamat website www.Atmaluhur.Ac.Id/.../Laporan\%20hasil\%20pengolahan.

Hidayati, A., Fudholi, A., \& Sumarni. (2014). Analisis Kepuasan Mahasiswa Terhadap Kualitas Pelayanan Tenaga Administratif Di Fakultas Farmasi 
Universitas Ahmad Dahlan Yogyakarta diakses dari alamat website download. Portalgaruda.Org/Article.Php?...Analisis\%20kepuasan

Indrawati, A. (2011). Pengaruh Kualitas Layanan Lembaga Pendidikan terhadap Kepuasan Konsumen. Jurnal Ekonomi Bisnis, Th. 16, No. 1, Maret 2011.

Pedoman Survey Kepuasan Mahasiswa Universitas Muhammadiyah Surabaya.

Setyaningsiih, I. (2008). Kepuasan Pelajar sebagai Konsumen Sebuah Institusi Pendidikan Kaunia, IV(1), April 2008.

Shank, J. K., \& Govindarajan, V. (1993). Strategic Cost Management: The New tool for Competitive Advantage. The Free Press. Adivision os Simon \& Schulter Inc., N.Y., 1200 .

Sudarsono, B. (2014). Mengukur Total Quality Management (TQM) di Universitas. ORBITH, 10(3), Nopember 2014, 184-190

Supriyanto, A. (2011). Implementasi Total Quality Management dalam Sistem Manajemen Mutu Pembelajaran di Institusi Pendidikan. Cakrawala Pendidikan, Februari 2011, Th.XXX, No.1

Tjiptono, F., \& Diana, A. (2003). Total Quality Management (Edisi Revisi). Yogyakarta: Penerbit Andi.

Widarto. (2012). Penerapan Total Quality Management (TQM) di Fakultas Teknik UNY, diakses dari alamat website staff.uny.ac.id/...\%20 Widarto..../Total\%20 Quality\%20Management. 